Ann. Génét. Sél. anim., I978, 10 (2), 251-257

\title{
Genetic and phenotypic parameters of the components parts of egg weight in Fayoumi and Rhode Island Reds
}

\author{
A. MOSTAGEER and A. OBEIDAH \\ Animal Breeding Department, \\ Faculty of Agriculture, Cairo University
}

\section{Summary}

The nineth and tenth eggs laid by each of I593 Fayoumi and 465 R.I.R. pullets (i.e., a total of 3.186 Fayoumi eggs and 930 R.I.R. eggs) were used to study the weight of the egg and its three components. The Fayoumi pullets represent 80 sire families and 345 dam families, and the R.I.R. ones represent 40 sire families and $\mathrm{r} 4 \mathrm{I}$ dam families. Data were corrected for hatch effects before performing the variance and covariance analysis to estimate the heritability values beside the genetic and phenotypic correlations.

The combined estimates of heritability were $0.293 \pm 0.054,0.226 \pm 0.049,0.310 \pm 0.054$, and $0.25 \mathrm{I} \pm 0.047$ for Fayoumi egg weight, yolk weight, albumen weight and shell weight respectively. The corresponding figures for R.I.R. were $0.365 \pm 0$. IIo, $0.326 \pm 0.106,0.536 \pm$ O.II5 and $0.578 \pm 0.116$.

It was shown that each gram of genetic gain in egg weight obtained through direct selection for this trait is composed of: and

$0.302 \mathrm{gm}$. yolk, $0.602 \mathrm{gm}$. albumen and $0.096 \mathrm{gm}$. shell in Fayoumi

o.II3 gm. yolk, o.8 Io gm. albumen and $0.077 \mathrm{gm}$. shell in R.I.R.

\section{Introduction}

The inheritance of the weights of the three components of the egg has not received the attention paid to egg weight. Studying the genetics of the three components of the egg may help the breeder in meeting the consumers demands and some requirements of good marketing. In this country (Egypt) the consumer pays much attention to yolk percentage, and it is of interest to know the consequences of breeding for higher egg weight on the relative weights of the egg components. The breaking strength of the egg is a function of shell percentage and shell thickness (Morgan, I932; Hale, I954; RIChard and STALEY, I967). Shell weight and percentage have their considerable significance from the marketing 
point of view, and genetic selection for egg weight may have indirect effect on these two characteristics of the shell.

The present study was carried out to investigate the inheritance of the weight of the egg and its components. The work was done on Fayoumi, a native breed of chicken characterized by its high percentage of egg yolk and egg shell (MOSTAGEER and KAMAR, I96I), and the Rhode Island Red breed.

\section{Material and methods}

This work was carried out in the Poultry Breeding Farm, Faculty of Agriculture, Cairo University. The nineth and tenth eggs laid by each of ${ }_{5} 93$ Fayoumi and 465 R.I.R. pullets (that is; a total of 3 I86 Fayoumi eggs and 930 R.I.R. eggs) were used for this study. The Fayoumi pullets represent 80 sire families and 345 dam families and were obtained in 15 different hatches in two different seasons. The R.I.R. birds were the daughters of 40 sires and I4I dams and were obtained in five hatches in one season. The Fayoumi and R.I.R. stocks used were not previously subjected to genetic selection and are considered non inbred.

Eggs were weighed before breaking, and the yolk and shell (with its membranes) were freed and weighed as described by HAFEZ, BADRELDIN and KAMAR (1955). Albumen weight was obtained by diflerence.

Data were corrected for hatch effects before performing the genetic analyses. Sire heritabilities $\left(h^{2}\right)$, dam heritabilities $\left(h^{2}\right)$, combined heritabilities $\left(h^{2}{ }_{c}\right)$ and combined genetic correlations $\left(r_{g}\right)$ beside the phenotypic correlations were estimated by the variance and covariance component analysis. The standard errors of heritability values were estimated by the method suggested by WooLF (I96I), and those of the genetic correlations were calculated after ROBERTSON (I959).

\section{Results and discussion}

\section{a) The means and variances}

The means, genetic variances (taken as double the sum of the sire and the dam components of variance) and phenotypic variances of egg weight and its component parts in both Fayoumi and R.I.R. are given in table I. A large difference can be observed between the two breeds with respect to egg weight (more than Io grams). Most of this difference (ca 8 grams) is attributed to the difference in albumen weight. The difference between the two breeds in shell weight is small (0.I5 grams). Studying three different breeds, MAY and STADELMAN (I960) observed no significant differences between breeds with respect to shell weight, although differences did exist with respect to egg weight. Differences in egg weight, however, were not of the magnitude observed here between Fayoumi and R.I.R.

It may be of interest here to note that the percentages of yolk, white and shell in the Fayoumi egg are respectively: 3I.II, 57.86 and II.03. The corresponding percentages in the R.I.R. egg are 29.09, 6r.82 and 9.09. The difference between the two breeds in the percentage of yolk as such is not much pronounced to be 
TABLE I

Means, genetic $\left(^{*}\right)\left(\sigma_{g}^{2}\right)$ and phenotypic $\left(\sigma_{p}^{2}\right)$ variances of egg weight and its three components in Fayoumi and R.I.R.

Moyenne, variance génétique $\left(\sigma_{g}^{2}\right)$ et phénotypique $\left(\sigma_{p}^{2}\right)$ du poids de l'œuf et de ses trois composantes chez la Fayoumi et la R.I.R.

\begin{tabular}{|c|c|c|c|c|c|c|c|}
\hline \multicolumn{4}{|c|}{ Breed } & $\begin{array}{c}\text { Eggg } \\
\text { weight }\end{array}$ & $\begin{array}{c}\text { Yolk } \\
\text { weight }\end{array}$ & $\begin{array}{c}\text { Albumen } \\
\text { weight }\end{array}$ & $\begin{array}{l}\text { Shell } \\
\text { weight }\end{array}$ \\
\hline Fayoumi & $\left\{\begin{array}{l}\text { Mean } \\
\sigma_{g}^{2} \cdot . \\
\sigma_{p}^{2} .\end{array}\right.$ & $\begin{array}{lll}\cdot & \cdot & . \\
. & \cdot & . \\
. & . & .\end{array}$ & . & $\begin{array}{c}4^{0.34} \\
6.758 \\
23.086\end{array}$ & $\begin{array}{c}\text { I } 2.55 \\
0.868 \\
3.84 \text { I }\end{array}$ & $\begin{array}{c}23.34 \\
2.676 \\
8.639\end{array}$ & $\begin{array}{l}4.45 \\
0.088 \\
0.347\end{array}$ \\
\hline R.I.R. & $\begin{array}{l}\text { Mean } \\
\sigma_{g}^{2} . \\
\sigma_{p}^{2} .\end{array}$ & 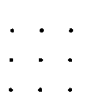 & . & $\begin{array}{c}50.63 \\
9.760 \\
26.774\end{array}$ & $\begin{array}{c}\mathrm{I} 4.73 \\
0.992 \\
3.039\end{array}$ & $\begin{array}{r}31.30 \\
7.426 \\
13.866\end{array}$ & $\begin{array}{l}4.60 \\
0.222 \\
0.385\end{array}$ \\
\hline
\end{tabular}

$\left(^{*}\right) \sigma^{2} g=2\left(\sigma^{2} s+\sigma^{2} d\right)$.

noticed and appraised by the consumer. Rather, the attention of the consumer is paid, it seems, to the percentage of yolk to albumen, a ratio which reaches the value of $53.77 \mathrm{p}$. Ioo in the Fayoumi egg and is only $47.06 \mathrm{p}$. Ioo in the R.I.R. egg.

The estimates of the genetic variance of the weight of the egg and its three components were all higher in R.I.R. than in Fayoumi, though the difference with respect to yolk weight was not very high. It can also be noticed that the R.I.R. breed, compared to Fayoumi, showed significantly higher estimates of phenotypic variability in egg and albumen weights and lower estimates for yolk weight. The difference between the two breeds in the phenotypic variance of shell weight was not very high ( 0.347 in Fayoumi and 0.385 in R.I.R.).

\section{b) The heritability estimates}

The heritability estimates of egg weight and the weights of its three components in the two breeds under investigation are presented in table 2 . It can be observed in Fayoumi that the sire heritability estimates of egg, yolk and albumen weights are higher than their corresponding dam heritabilities, indicating the possibility of sex linked genes involved in the inheritance of these characters. Such was not the case in R.I.R., in which dam heritabilities were higher than the sire heritabilities in the four traits studied. It must be stated, however, that differences between sire and dam heritabilities in both breeds did not reach the level of significance for all the characters studied.

The combined heritability estimates of egg weight and the weights of its three component parts are all higher in R.I.R. than their corresponding estimates in Fayoumi. In both breeds, yolk weight showed the lowest value of combined heritability compared to the weights of egg, white and shell. 
TABLE 2

The heritability values (土 S.E.) of egg weight and its three components in Fayoumi and R.I.R.

Valeurs d'héritabilité ( \pm écart-type) du poids de l'œuf et de ses trois composantes chez la Fayoumi et la R.I.R.

\begin{tabular}{|c|c|c|c|c|c|c|}
\hline \multicolumn{3}{|c|}{ Breed } & $\begin{array}{c}\text { Egg } \\
\text { weight }\end{array}$ & $\begin{array}{c}\text { Yolk } \\
\text { weight }\end{array}$ & $\begin{array}{l}\text { Albumen } \\
\text { weight }\end{array}$ & $\begin{array}{c}\text { Shell } \\
\text { weight }\end{array}$ \\
\hline Fayoumi & $\begin{array}{l}h_{s}^{2} \\
h_{d}^{2} \\
h_{c}^{2}\end{array}$ & $\begin{array}{l}\cdot \\
\cdot \\
\cdot \\
\cdot\end{array}$ & $\begin{array}{l}0.332 \pm 0.086 \\
0.253 \pm 0.089 \\
0.293 \pm 0.054\end{array}$ & $\begin{array}{l}0.24 \mathrm{I} \pm 0.073 \\
0.212 \pm 0.087 \\
0.226 \pm 0.049\end{array}$ & $\begin{array}{l}0.387 \pm 0.090 \\
0.233 \pm 0.082 \\
0.310 \pm 0.054\end{array}$ & $\begin{array}{l}0.206 \pm 0.070 \\
0.296 \pm 0.088 \\
0.251 \pm 0.047\end{array}$ \\
\hline R.I.R. & $\begin{array}{l}h_{s}^{2} \\
h_{d}^{2} \\
h_{c}^{2}\end{array}$. & $\begin{array}{l}\cdot . \\
\cdot . \\
. \\
.\end{array}$ & $\begin{array}{l}0.298 \pm 0.165 \\
0.431 \pm 0.217 \\
0.365 \pm 0.110\end{array}$ & $\begin{array}{l}0.247 \pm 0.155 \\
0.405 \pm 0.214 \\
0.326 \pm 0.106\end{array}$ & $\begin{array}{l}0.319 \pm 0.187 \\
0.75^{2} \pm 0.237 \\
0.536 \pm 0.115\end{array}$ & $\begin{array}{l}0.448 \pm 0.201 \\
0.708 \pm 0.225 \\
0.578 \pm 0.116\end{array}$ \\
\hline
\end{tabular}

Estimates of heritability of the component parts of the egg were reported by Scheinberg, WARD and Nordskog (I953) and YAo and Skinner (I959). The heritability estimates obtained by HILI, KRUEGER and QUISENBERRY (I966) for yolk, white and shell weights are closer to the estimates obtained in this study for R.I.R.

\section{c) Genetic and phenotypic correlations}

The genetic and phenotypic correlations between the four characters studied are given in table 3. In Fayoumi, egg weight is genetically highly correlated with the weights of its three components; $r_{g}$ of egg weight reached the value of 0.96 with albumen weight and 0.84 with yolk and shell weights. The three components of the Fayoumi egg are also significantly correlated with each other, the highest correlation (o.8) was between albumen and shell weights.

The R.I.R. showed a different picture. The yolk weight of the R.I.R. egg was not significantly correlated genetically with egg weight or with its other two components. Shell weight showed lower genetic correlations with egg weight and albumen weight (0.5I and 0.35 resp.) compared with those observed in Fayoumi. The genetic correlations observed by YAO and SkINNER (I959) between egg weight and each of yolk and albumen weight (0.7I and 0.98 resp.) are much higher than those obtained in R.I.R. in this study and closer to those of Fayoumi.

The phenotypic correlations in Fayoumi are all a bit lower than their corresponding genetic correlations. In R.I.R., however, the reverse is true. Yolk weight in R.I.R. showed significant phenotypic correlations with the other three traits studied.

Using the estimates shown in tables $\mathrm{I}, 2$ and 3 , it is of interest to predict the consequences of genetic selection on the component parts of the egg. In Fayoumi, if we select for egg weight, it can be shown that each gram of genetic 
TABLE 3

Genetic and phenotypic correlations ( \pm S.E.) between egg weight and its three components in Fayoumi and R.I.R.

Corrélations génétiques et phénotypiques ( + écart-type) entre le poids de l'aut et ses trois composantes chez la Fayoumi et la R.I.R.

\begin{tabular}{|c|c|c|c|c|c|}
\hline & & $\begin{array}{c}\text { Egg } \\
\text { weight } \\
\text { (gm) }\end{array}$ & $\begin{array}{c}\text { Yolk } \\
\text { weight } \\
\text { (gim) }\end{array}$ & $\begin{array}{l}\text { Albumen } \\
\text { weight } \\
\text { (gm) }\end{array}$ & $\begin{array}{c}\text { Shell } \\
\text { weight } \\
\text { (gm) }\end{array}$ \\
\hline Fayoumi & $\begin{array}{l}\text { Egg wt. . } \\
\text { Yolk wt. . } \\
\text { Albumen wt. } \\
\text { Shell wt. . . }\end{array}$ & $\begin{array}{l}0.844 \pm 0.040 \\
0.956 \pm 0.011 \\
0.846 \pm 0.037\end{array}$ & $\begin{array}{l}0.882 \pm 0.008 \\
0.656 \pm 0.077 \\
0.638 \pm 0.084\end{array}$ & $\begin{array}{l}0.926 \pm 0.004 \\
0.556 \pm 0.017 \\
0.800 \pm 0.046\end{array}$ & $\begin{array}{l}0.804 \pm 0.009 \\
0.602 \pm 0.016 \\
0.712 \pm 0.012\end{array}$ \\
\hline R.I.R. & $\begin{array}{l}\text { Egg wt.. . } \\
\text { Yolk wt. } \\
\text { Albumen wt. } \\
\text { Shell wt. . }\end{array}$ & $\begin{array}{l}0.354 \pm 0.193 \\
0.929 \pm 0.025 \\
0.510 \pm 0.129\end{array}$ & $\begin{array}{l}0.718 \pm 0.023 \\
0.012 \pm 0.186 \\
0.168 \pm 0.178\end{array}$ & $\begin{array}{l}0.937 \pm 0.006 \\
0.443 \pm 0.037 \\
0.350 \pm 0.129\end{array}$ & $\begin{array}{l}0.701 \pm 0.024 \\
0.207 \pm 0.044 \\
0.564 \pm 0.032\end{array}$ \\
\hline
\end{tabular}
lations.

Figures above diagonal are phenotypic correlations and below diagonal are combined genetic corre-

increase in egg weight will be distributed between the three components of egg as follows:

$0.302 \mathrm{gm}$. yolk, $0.602 \mathrm{gm}$. albumen and $0.096 \mathrm{gm}$. shell.

Comparing these values with the percentages described above of the three components of the Fayoumi egg, it can be seen that direct selection for higher egg weight in this breed will result in increasing white percentage on the expense of yolk and shell percentages.

With similar argument, it can be shown that the genetic increase of one gram in the R.I.R. egg obtained through direct selection for this trait will be distributed as follows:

0.II3 gm. yolk, 0.8Io gm. albumen and $0.077 \mathrm{gm}$. shell.

Again the genetic increase of egg weight by direct selection in this breed will be mostly in albumen, but the increase in white percentage in the R.I.R. egg will be much more pronounced than in the Fayoumi egg.

The genetic increase in egg weight could, however, be obtained indirectly through selection for one of the three components of the egg. The relative efficiency of gain in egg weight arrived at through direct selection to that obtained through indirect selection is $h_{1}: r_{g} h_{2}$, where $h^{2}{ }_{1}$ is the heritability of egg weight and $h^{2}$ is the heritability of the other trait. Thus, in Fayoumi, if selection is directed to the weight of the yolk rather than the weight of the egg, it can be shown that every gram of genetic gain in egg weight obtained through this indirect selection is distributed as follows:

$0.425 \mathrm{gm}$. yolk, $0.489 \mathrm{gm}$. albumen and $0.086 \mathrm{gm}$. shell.

Clearly, here we gain in yolk percentage on the expense of albumen and shell 
percentages, but the efficiency of genetic gain in egg weight will be only $74 \mathrm{p}$. IOo of the efficiency of direct selection. If yolk has its economic significance in Fayoumi, as the case seems to be in this country, a proper evaluation of this significance should be done. This will enable the breeder to evaluate the economic consequences of different selection indices and choose the most appropriate one.

It can be also shown that the one gram indirect genetic increase in Fayoumi egg weight gained through selection on albumen weight is distributed as follows: $0.246 \mathrm{gm}$. yolk, $0.65^{8} \mathrm{gm}$. albumen and $0.096 \mathrm{gm}$. shell,

with a relative efficiency of $9^{8} \mathrm{p}$. IOO, and the distribution when selecting on shell weight will be:

$0.270 \mathrm{gm}$. yolk, $0.595 \mathrm{gm}$. albumen and o.r35 gm. shell, (with a relative efficiency of $78 \mathrm{p}$. IOo). Selection on shell weight will increase the percentages of both shell and albumen on the expense of yolk percentage.

$$
\text { Reçu pour publication en juillet } 1978 \text {. }
$$

\title{
Résumé
}

\author{
Paramètres génétiques et phénotypiques des composantes \\ $d u$ poids de l'cuf chez des Fayoumi et des Rhode-Island rouges
}

Le neuvième et le dixième œuf pondus par I 593 poulettes Fayoumi et 465 poulettes R.I.R. (soit un total de 3 r 86 œufs de Fayoumi et 930 œufs de R.I.R.) ont servi à l'étude du poids de l'œuf et de ses trois composantes. Les poulettes Fayoumi représentent 80 familles de même père et 345 familles de même mère, et les R.I.R. représentent la descendance de 40 pères et I $4 \mathrm{I}$ mères. Les données sont corrigées pour les effets de date d'éclosion avant la mise en œuvre d'analyses de variance et de covariance pour estimer les valeurs d'héritabilité et les corrélations phénotypiques et génétiques.

Les estimations combinées de l'héritabilité étaient $0,293 \pm 0,054,0,226 \pm 0,049,0,310 \pm$ 0,054 , et $0,25 \mathrm{I} \pm 0,047$ respectivement pour le poids de l'ouf, du jaune, de l'albumen et de la coquille chez la Fayoumi. Les valeurs correspondantes pour la R.I.R. étaient $0,365 \pm 0,110$, $0,326 \pm 0,106,0,536 \pm 0,115$ et $0,578 \pm 0,116$.

Il est montré que chaque gramme de gain génétique sur le poids de l'œuf obtenu par sélection directe pour ce caractère est composé de $0,302 \mathrm{~g}$ de jaune, $0,602 \mathrm{~g}$ d'albumen et $0,096 \mathrm{~g}$ de coquille chez la Fayoumi, et de o, I I3 $\mathrm{g}$ de jaune, o,8 Io g d'albumen et o,077 $\mathrm{g}$ de coquille chez la R.I.R.

\section{References}

HAFEz E. S. E., Badreidin A. L., KamaR G. A. R., 1955. Egg components in the Fayoumi fowl during the first laying year. Poult. Sci., 34, 16-27.

HAIE R. W., I954. Observations on the shell strength of hen eggs. Res. Expt. Rec. Min. Agric. N. Ire., 4, 34-40.

HiLl A. T., KRUEGER W. F., QUISENBERRY J. H., ig66. A biometrical evaluation of the component parts of eggs and their relations hips to other economically important traits in a strain of White Leghorns. Poult. Sci., 45, 1 I62-1 185.

May K. N., Stadelman W. J., I96o. Some factors affecting components of eggs from adult hens. Poult. Sci., 39, 560-565.

MorGan C. L., I932. Relationship between breaking strength and percentage of egg shell. Poult. Sci., 11, I72-I75.

Mostageer A., Kamar G. A. R., r96r. On the inheritance of egg weight. Poult. Sci., 40, 857860. 
RICHARD J. F., STALEY L. M., I967. The relationships between crushing strength, deformation and other physical measurements of the hen's egg. Poult. Sci., 46, 430-437.

ROBERTSON A., 1959. The sampling variance of the genetic correlation coefficient. Biometrics, $15,469-485$.

SChEINBERG S. L., WARD H., NoRdSkoG A. W., I953. Breeding for egg quality. I. Heritability and repeatability of egg weight and its components. Poult. Sci., 32, 504-5Io.

Woolf B., I96r. Lecture notes to the students of the Diploma in Animal Genetics, Edinburgh University.

YAo K. T. S., SkINNER J. L., r959. Heritability and genetic correlations of albumen weight and yolk size in chicken eggs. Poult. Sci., 38, 1262. 